\title{
Dry Reforming of Methane at Moderate Temperatures Over Modified Co-Al Co-precipitated Catalysts
}

\author{
Guilherme de Souza, Nilson Romeu Marcilio, Oscar William Perez-Lopez*
}

\author{
Department of Chemical Engineering, Federal University of Rio Grande do Sul - UFRGS, \\ Rua Eng. Luiz Englert, s/n, CEP 90040-040, Porto Alegre, RS, Brazil
}

Received: February 3, 2014; Revised: May 25, 2014

\begin{abstract}
M-Co- $\mathrm{Al}(\mathrm{M}=\mathrm{Ca}, \mathrm{La}, \mathrm{Li}$ or $\mathrm{Mg})$ materials were synthesised by co-precipitation and investigated for dry reforming of methane. Thermogravimetry, temperature-programmed oxidation, reduction and $\mathrm{CO}_{2}$ desorption, specific area and $\mathrm{X}$-ray diffraction were utilised for characterisation. Activity tests were conducted at atmospheric pressure, temperatures between $400-550^{\circ} \mathrm{C}, \mathrm{CH}_{4} / \mathrm{CO}_{2}$ molar ratio of 1 and GHSV of $6000 \mathrm{NmL} \mathrm{CH}_{4} \cdot \mathrm{g}^{-1} \cdot \mathrm{h}^{-1}$. The partial substitution of Co by a third element increased the area and changed the acid/base properties, reducibility and crystallinity of the oxides. These modifications resulted in higher activity for dry reforming of methane, mainly related to the decrease in the acidity of the promoted materials and, consequently, lower carbon formation. The Li-modified sample presented the lowest coke deposition due to the increase in stronger basic sites. The Mg-promoted catalyst exhibited the best activity performance. This depicts the enhancement in the reducibility and acid/base properties found in the MgCoAl sample.
\end{abstract}

Keywords: Dry reforming of methane, Co-based catalyst, carbon deposition, precipitation method, mixed oxides.

\section{Introduction}

Carbon dioxide reforming of methane is an interesting route for converting natural gas into synthesis gas (or syngas), which can generate a wide range of products such as clean transportation fuels and other chemicals. The increase in the known reserves of natural gas and the feasibility of exploring natural reserves in remote locations several kilometres from the coast and in small fields stimulate the development of Gas-To-Liquids (GTL) technology. These reserves usually cannot be monetised by using conventional technologies such as pipelines or liquefied natural gas $^{1,2}$, promoting the conversion in loco of the gas. The process is also environmentally friendly because fuels are being produced from both greenhouse gases in this case.

The transition metals from group VIII of the periodic table are active for reforming processes. Among the referred elements, the literature points to $\mathrm{Ru}$ and $\mathrm{Rh}$ as the most active metals, followed by $\mathrm{Ni}, \mathrm{Ir}, \mathrm{Pt}, \mathrm{Pd}$ and $\mathrm{Co}^{3,4}$. The catalysts based on noble metals exhibit a lower carbon formation rate compared to $\mathrm{Ni}$ - and Co-samples, leading to less dissolution of carbon into these metals ${ }^{4}$. However, the lower price is an incentive for the use of Ni- and Co-based catalysts, mainly Ni-samples. Nickel presents very high activity for methanation, so its fines could possibly promote this reaction for the downstream tail gas. Therefore, cobalt catalysts could be an interesting alternative that avoids this drawback ${ }^{5}$. Moreover, related papers reported higher activity for Co-based catalysts compared to Ni-based samples that were prepared either by the precipitation or impregnation methods ${ }^{6,7}$.

*e-mail address: perez@enq.ufrgs.br
So far, most of the studies for dry reforming of methane over cobalt materials in the literature explore supported catalysts ${ }^{5,8,9}$. For dry reforming of methane over Co-supported catalysts, previous works showed that the presence of alkalis or small quantities of noble metals could slow down the reoxidation of metallic cobalt and the formation of coke $\mathrm{e}^{5,10,11}$. For example, Bouarab et al. showed that the addition of $\mathrm{La}_{2} \mathrm{O}_{3}$ or $\mathrm{MgO}$ to $\mathrm{Co} / \mathrm{SiO}_{2}$ could change the acid-base properties of this material ${ }^{5}$. As a result, this material inhibits coke formation by the adsorption of $\mathrm{CO}_{2}$ species on the surface and hence promotes $\mathrm{CO}_{2}$ reaction with deposited carbon by the reverse of the Boudouard reaction ${ }^{5}$. In the same way, Fakeeha and co-workers revealed that addition of $\mathrm{Sr}$ leads to coke suppression by improving the interaction between Co and the support and the Lewis basicity of the samples ${ }^{12}$. Similar results for alkali promotion were observed for Ni-based catalysts, which included $\mathrm{K}$, $\mathrm{Li}, \mathrm{La}, \mathrm{Mg}, \mathrm{Ba}$ and $\mathrm{Ca}^{13-19}$. Moreover, this promotion can be performed by adding the alkali directly during the synthesis of co-precipitated samples. This preparation method can originate mixed oxides, which have desirable properties such as high surface area, high thermal stability and small crystallite sizes ${ }^{20,21}$. Indeed, several nickel-spinel oxides have shown excellent results for dry reforming of methane ${ }^{22-28}$. According to Bhattacharyya et al., the mixed oxide materials derived from a hydrotalcite-type (HT) structure might provide a random distribution of the divalent metal ions $\left(\mathrm{M}^{2+}\right)$ in the layered structure. The active metal ions should be surrounded by other ions that might minimise aggregation and thus prevent sintering and coke formation ${ }^{26}$. Additionally, promising results have been achieved by 
similar mixed oxide materials based on cobalt in different processes $^{29-31}$, and these results lead to the investigation of dry reforming of $\mathrm{CH}_{4}$ on Co-mixed oxide catalysts.

The present work investigates the two mentioned strategies, i.e., the $\mathrm{CO}_{2}$ reforming of methane over $\mathrm{Co}-\mathrm{Al}$ mixed oxide materials modified with alkali elements such as $\mathrm{Ca}, \mathrm{La}, \mathrm{Li}$ or $\mathrm{Mg}$. The third element was chosen based on the effect of slowing down the reoxidation of metallic $\mathrm{Ni}$ or Co described earlier. The different charges and ionic radii, which increase in the order $\mathrm{Li}^{+}<\mathrm{Mg}^{2+}<\mathrm{Co}^{2+}<\mathrm{Ca}^{2+}$ $<\mathrm{La}^{3+}$, were also taken into account for selecting the metal because these properties can lead to different structures of the mixed oxides.

\section{Experimental}

The catalysts were synthesised by the co-precipitation method using two aqueous solutions. The first solution contained an aqueous mixture of aluminium nitrate and cobalt nitrate, and for the modified Co-Al samples a third nitrate salt was added ( $\mathrm{Ca}, \mathrm{Li}, \mathrm{La}$ or $\mathrm{Mg}$ ). An aqueous solution of $\mathrm{Na}_{2} \mathrm{CO}_{3}$ was used as the precipitant. Both solutions were continuously added into a continuous stirredtank reactor (CSTR) at a constant temperature $\left(50^{\circ} \mathrm{C}\right)$ and $\mathrm{pH}(8 \pm 0.1)$. The precipitate was collected and kept under stirring at $50^{\circ} \mathrm{C}$ for $1 \mathrm{~h}$. After crystallisation, the precipitate was vacuum filtered and washed with deionised water. This process was conducted until the conductivity value of the filtrate was lower than $50 \mu \mathrm{S} \cdot \mathrm{cm}^{-1}$. This value ensures that the ions from the precursors (mostly $\mathrm{Na}^{+}$) were almost completely removed. Then, the material was dried at $80^{\circ} \mathrm{C}$ for $24 \mathrm{~h}$ in an oven. The obtained solids were crushed and sieved to the desired particle sizes $\left(355<d_{p}<500 \mu \mathrm{m}\right)$ and calcined under a continuous air flow $\left(50 \mathrm{~mL} \cdot \mathrm{min}^{-1}\right)$ at $600^{\circ} \mathrm{C}$ for $6 \mathrm{~h}$.

The materials were characterised by surface area measurements $\left(\mathrm{S}_{\mathrm{BET}}\right)$, thermogravimetry (TG/DTA), X-ray diffraction (XRD), temperature-programmed reduction $\left(\mathrm{H}_{2}\right.$-TPR), temperature-programmed desorption of dioxide carbon $\left(\mathrm{CO}_{2}\right.$-TPD) and temperature-programmed oxidation (TPO/DTA). The XRD patterns were collected with a Bruker D2 Phaser X-ray diffractometer using $\mathrm{CuK} \alpha$ radiation. The $\mathrm{Co}^{0}$ apparent crystallite sizes were calculated by the Scherrer equation from the reflection at $2 \theta=44.3^{\circ}$. The TG/DTA and TPO/DTA analysis were performed in a TA thermobalance (Model SDT Q600). After pretreatment at room temperature with $\mathrm{N}_{2}$ flow, $10 \mathrm{mg}$ of uncalcined (TG/DTA) or spent sample (TPO/DTA) was heated to approximately $850^{\circ} \mathrm{C}$ at a rate of $10^{\circ} \mathrm{C} \cdot \mathrm{min}^{-1}$ under an air flow rate of $100 \mathrm{~mL} \cdot \mathrm{min}^{-1}$. The $\mathrm{S}_{\mathrm{BET}}$ were obtained by the
$\mathrm{N}_{2}$ dynamic adsorption method at the normal boiling point of $\mathrm{N}_{2}\left(-196^{\circ} \mathrm{C}\right)$. The $\mathrm{CO}_{2}$-TPD curves were collected using a multipurpose system (SAMP3). Approximately $100 \mathrm{mg}$ of the calcined sample was placed in a quartz tube located in a temperature-controlled oven. After being outgassed at $250^{\circ} \mathrm{C}$ under $\mathrm{N}_{2}$ flow for $1 \mathrm{~h}$, the sample was saturated with $\mathrm{CO}_{2}$ at $100^{\circ} \mathrm{C}$ for $30 \mathrm{~min}$ followed by a purge with $\mathrm{He}$ for $30 \mathrm{~min}$. The desorption curves were recorded with a thermal conductivity detector (TCD) by increasing the temperature form $100^{\circ} \mathrm{C}$ to $600^{\circ} \mathrm{C}\left(10^{\circ} \mathrm{C} \cdot \mathrm{min}^{-1}\right)$ under a $30 \mathrm{~mL} \cdot \mathrm{min}^{-1}$ He flow. The $\mathrm{H}_{2}$-TPR analysis was carried out in the same multipurpose system, where the temperature was increased to $c a .900^{\circ} \mathrm{C}\left(10^{\circ} \mathrm{C} \cdot \mathrm{min}^{-1}\right)$ using $30 \mathrm{~mL} \cdot \mathrm{min}^{-1}$ of a reduction mixture containing $10 \% \mathrm{H}_{2} / \mathrm{N}_{2}(\mathrm{v} / \mathrm{v})$.

The dry reforming of methane tests were performed under atmospheric pressure in a fixed-bed quartz reactor ( $1 / 2$ in. diameter) loaded with $100 \mathrm{mg}$ of catalyst diluted with quartz $(1: 2 \mathrm{v} / \mathrm{v})$ and using quartz wool as the support for the catalytic bed. The samples were reduced in situ for $1 \mathrm{~h}$ at $700^{\circ} \mathrm{C}\left(5^{\circ} \mathrm{C} \cdot \mathrm{min}^{-1}\right)$ under $50 \mathrm{~mL} \cdot \mathrm{min}^{-1}$ of a $10 \% \mathrm{H}_{2} / \mathrm{N}_{2}(\mathrm{v} / \mathrm{v})$ mixture prior to the reactions. The runs were carried out at temperatures between 400 and $550^{\circ} \mathrm{C}$ using a $\mathrm{CO}_{2} / \mathrm{CH}_{4}$ molar ratio of 1 . These operational conditions might coincide with regions of increased thermodynamic potential for carbon formation $^{32,33}$, which is a more interesting condition to investigate the effect of alkali promotion on the deactivation of catalyst due to coke deposition. The gas hourly space velocity (GHSV) was approximately $6000 \mathrm{~mL} \mathrm{CH} \cdot \mathrm{CH}^{-1} \cdot \mathrm{h}^{-1}$. The $\mathrm{CH}_{4}$ and $\mathrm{CO}_{2}$ conversions were calculated using an online gas chromatograph equipped with a TCD. The reactor exit gas mixture was injected three times at each reaction temperature value (average standard deviation $<1$ ). The conversion values were obtained by the difference between the measured area and the corresponding area collected in blank injections, which was performed by bypassing the reactor. The reaction was also kept at $500^{\circ} \mathrm{C}$ for $5 \mathrm{~h}$ to evaluate the thermal stability and the coke deposition.

\section{Results and Discussion}

The catalyst nomenclature, the nominal composition and the TGA/DTA results are summarised in Table 1. The thermogravimetric curves obtained for the LiCoAl sample are presented in Figure 1, which includes the derivative thermogravimetric analysis (DTG) and the differential thermal analysis (DTA).

As illustrated in Figure 1, two major weight losses and endothermic peaks are observed. The first weight loss (approximately 15 to 20\%) is an endothermic event that takes place at temperatures between 200 and $211^{\circ} \mathrm{C}$.

Table 1. Weight loss and DTA data obtained from thermogravimetry for uncalcined samples.

\begin{tabular}{|c|c|c|c|c|c|c|c|c|}
\hline \multirow{2}{*}{ Sample } & \multirow{2}{*}{$\begin{array}{l}\text { Third element } \\
\text { (M) }\end{array}$} & \multicolumn{3}{|c|}{ Composition (mol \%) } & \multirow{2}{*}{$\begin{array}{c}\text { Total weight loss } \\
(\%)\end{array}$} & \multicolumn{3}{|c|}{ DTA peak temperature $\left({ }^{\circ} \mathrm{C}\right)$} \\
\hline & & $\mathbf{M}$ & Co & Al & & $1^{\text {st }}$ peak & $2^{\text {nd }}$ peak & $3^{\text {rd }}$ peak \\
\hline $\mathrm{CoAl}$ & - & 0.0 & 66.7 & 33.3 & 27.1 & 209 & 248 & - \\
\hline CaCoAl & $\mathrm{Ca}$ & 11.1 & 55.6 & 33.3 & 34.9 & 206 & 249 & - \\
\hline $\mathrm{LaCoAl}$ & $\mathrm{La}$ & 11.1 & 55.6 & 33.3 & 27.3 & 200 & 248 & 441 \\
\hline LiCoAl & $\mathrm{Li}$ & 11.1 & 55.6 & 33.3 & 29.8 & 201 & 250 & - \\
\hline $\mathrm{MgCoAl}$ & $\mathrm{Mg}$ & 11.1 & 55.6 & 33.3 & 31.0 & 211 & 268 & - \\
\hline
\end{tabular}


This transition is related to the release of interlayer water molecules from the structure. The second DTG-DTA peak occurs at temperatures between 248 and $268^{\circ} \mathrm{C}$ and is commonly ascribed to the removal of hydroxyl host-layers and $\mathrm{CO}_{3}{ }^{2-}$ from the structure ${ }^{34}$, although this peak might include the release of NO provided by the decomposition of nitrates from the precursors. Table 1 shows that the second peak is shifted towards higher temperatures for the $\mathrm{MgCoAl}$ sample, which suggests a higher thermal stability for this material ${ }^{35}$. The endothermic effects are typically observed in the thermal decomposition of anionic clays ${ }^{36-38}$. These peaks indicate that the layered structure collapses below $400^{\circ} \mathrm{C}$, yielding the mixed metal oxides ${ }^{39}$. Nonetheless, the LaCoAl sample exhibits an additional endothermic DTA peak located at $441^{\circ} \mathrm{C}$, which is followed by a small weight loss (not showed). This phenomenon should be related to changes in the oxidative state of La. The total weight loss varies between 27.1 and $34.9 \%$. The position and the relative intensity of the DTG peaks are similar to the results reported by Wang et al. ${ }^{40}$ for Co-Al catalysts synthesised with a similar method.

The measurements of the BET specific surface area are shown in Table 2 . The standard sample (CoAl) exhibits a surface area value of $54 \mathrm{~m}^{2} \cdot \mathrm{g}^{-1}$. The specific surface area reported herein is the same value that was previously obtained for similar precipitated $\mathrm{Co}-\mathrm{Al}$ materials calcined at $600^{\circ} \mathrm{C}^{41}$. The partial substitution of Co by a third element with alkaline character increases the surface area. Although the modification with La gives the highest area, high areas (between 64 and $67 \mathrm{~m}^{2} \cdot \mathrm{g}^{-1}$ ) are clearly achieved when Co is partly substituted by another divalent element because the



Figure 1. Thermogravimetric curves collected for the LiCoAl sample: weight (solid line), derivative thermogravimetry (dotted line) and differential thermal analysis (dashed line).
$\mathrm{M}^{2+} / \mathrm{M}^{3+}$ ratio is kept at the same value claimed to form pure phases of HT compounds ${ }^{20}$. Indeed, the partial substitution of $\mathrm{Co}^{2+}$ by $\mathrm{Li}^{+}$minimally changes the surface area. The results suggest that the changes in the specific surface area might be related to the formation of different mixed oxide phases rather than the electronic aspects or ionic radii of the elements.

The XRD patterns of the calcined catalysts are shown in Figure 2. The catalysts exhibit similar patterns, with poorly crystalline structures, where the diffraction reflections assigned to the $\mathrm{Co}_{3} \mathrm{O}_{4}$ and the $\mathrm{CoAl}_{2} \mathrm{O}_{4}$ crystalline phases were detected for all the samples. Our group found the same cobalt oxide phases for the $\mathrm{Cu}-\mathrm{Co}-\mathrm{Al}$ catalysts, in which the promoter oxide also could not be observed, mostly due to the lower amount of this oxide ${ }^{42}$. Similar results regarding the formation of a lesser crystalline structure for the supported $\mathrm{La}-\mathrm{Co} / \mathrm{Al}_{2} \mathrm{O}_{3}$ catalyst was also reported by $\mathrm{Hu} \& \mathrm{Lu}^{43}$. For the $\mathrm{LaCoAl}$ catalyst, additional reflections indicate the presence of a segregated $\mathrm{La}_{2} \mathrm{O}_{3}$ phase. The $\mathrm{Co}_{3} \mathrm{O}_{4}$ crystallite sizes cannot be accurately estimated by XRD because of the low peak intensities and the overlapping of diffraction



Figure 2. XRD patterns for calcined samples. Identified crystalline phases: ( $\square) \mathrm{Co}_{3} \mathrm{O}_{4} ;(\mathrm{X}) \mathrm{CoAl}_{2} \mathrm{O}_{4} ;(\bullet) \mathrm{La}_{2} \mathrm{O}_{3}$.

Table 2. BET surface area, degree of reduction $(\%)$ and $\mathrm{Co}^{\circ}$ apparent crystallite diameter by XRD for calcined and reduced samples, respectively.

\begin{tabular}{cccc}
\hline Sample & $\mathbf{S}_{\mathbf{B E T}}\left(\mathbf{m}^{2} / \mathbf{g}\right)$ & Degree of reduction $(\boldsymbol{\%})$ & d by XRD $(\mathbf{n m})$ \\
\hline CoAl & 54 & 73 & 22 \\
CaCoAl & 64 & 69 & 34 \\
LaCoAl & 68 & 73 & 26 \\
LiCoAl & 56 & 73 & 25 \\
MgCoAl & 67 & 94 & 29 \\
\hline
\end{tabular}


peaks from both the identified Co oxide phases. However, changes in the crystallinity are caused by the presence of a third element. Indeed, the $\mathrm{MgCoAl}$ and $\mathrm{LiCoAl}$ samples show an increase in crystallinity, indicating the formation of a higher ordered mixed oxide structure.

The $\mathrm{H}_{2}$-TPR curves of the calcined samples are presented in Figure 3. The reduction peak centred at $424-495^{\circ} \mathrm{C}$ corresponds to the reduction of bulk cobalt oxide identified by XRD (i.e., $\left.\mathrm{Co}_{3} \mathrm{O}_{4} \rightarrow \mathrm{CoO} \rightarrow \mathrm{Co}^{0}\right)^{30,44,45}$. Additionally, the peak centred at higher temperatures $\left(724-764^{\circ} \mathrm{C}\right)$ can be ascribed to the reduction of $\mathrm{CoAl}_{2} \mathrm{O}_{4}$ phase, which should occur at higher temperatures due to the increased stabilisation of the $\mathrm{Co}^{2+}$ ions by the $\mathrm{Al}^{3+}$ ions in the spinel phase $\mathrm{e}^{8,30,46,47}$. Furthermore, the uptake of $\mathrm{H}_{2}$ at higher temperatures might include the reduction of other mixed oxide phases containing the promoters. Thereby, the reduction of mixed oxides such as $\mathrm{LaCoO}_{3}{ }^{48}$ and $\mathrm{Co}_{4} \mathrm{Mg}_{2} \mathrm{Al}_{2}{ }^{49}$ should take place at these temperatures. Although the referred mixed oxides cannot be identified by XRD due to the small peak intensities (Figure 2), the existence of such phases cannot be disregarded.

The overall shape of curves does not change significantly with the addition of a third element, but the reducibility of the phases and the degree of reduction are modified. Except

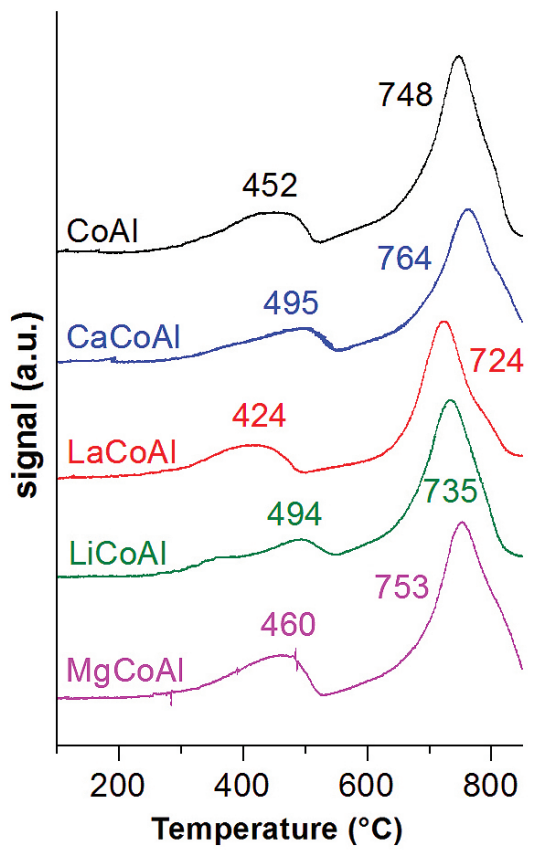

Figure 3. $\mathrm{H}_{2}-\mathrm{TPR}$ profiles. for the $\mathrm{MgCoAl}$ samples, the area of peaks decreases for the modified catalysts, mostly because there is a lower content of Co oxide to be reduced to the metallic phase. Indeed, the surface area measurements (Table 2) and the XRD patterns (Figure 2) reveal an influence of alkali content on crystallinity, while the TPR highlights that these modifications impact the reduction of the Co species. The partial substitution of $\mathrm{Co}$ by $\mathrm{Li}$ or $\mathrm{La}$ increases the reducibility of the $\mathrm{CoAl}_{2} \mathrm{O}_{4}$ phase, whereas an opposite trend is observed when $\mathrm{Co}$ is partly substituted by $\mathrm{Mg}$ or $\mathrm{Ca}$. The latter behaviour depicts a stronger interaction between the $\mathrm{Co}$ oxide and the $\mathrm{MgO}$ - or $\mathrm{CaO}$-modified support, which requires higher temperatures to be reduced. These results follow the same trend observed for other $\mathrm{Mg}-\mathrm{Co}-$ $\mathrm{Al}$ and for $\mathrm{CaO}-\mathrm{Ni} / \mathrm{Al}_{2} \mathrm{O}_{3}$ catalysts with similar loadings for the promoters ${ }^{14,16,29}$. Among the M-Co-Al catalysts, the LaCoAl sample exhibits well-defined behaviour, because both reduction peaks are located at significantly lower temperatures. This change in the reduction temperatures for LaCoAl might be caused by the presence of the segregated $\mathrm{La}_{2} \mathrm{O}_{3}$ phase (see the XRD pattern in Figure 2). The La oxide was found to promote the reduction of the Co species at lower temperatures ${ }^{48}$, which might weaken the interaction of Co with the Al oxide. Aside from the effect on the reduction temperatures, Table 2 shows that the alkalis do not change the degree of reduction with respect to the $\mathrm{CoAl}$ sample, except for the $\mathrm{MgCoAl}$ catalyst. This latter material exhibited an enhanced degree of reduction compared to the other samples (20\% higher). Apparently, magnesium causes changes in the properties of the material so that a higher fraction of the Co in the mixed oxides could be reduced to metallic cobalt.

Table 2 also shows the apparent $\mathrm{Co}^{0}$ crystallite size estimated from the XRD patterns for the reduced samples. Higher $\mathrm{Co}^{0}$ diameters are observed for the modified catalysts. The $\mathrm{Co}^{0}$ average size increases in the following order: $\mathrm{CoAl}<\mathrm{LiCoAl} \approx \mathrm{LaCoAl}<\mathrm{MgCoAl}<\mathrm{CaCoAl}$.

The $\mathrm{CO}_{2}$ desorption curves are exhibited in Figure 4. There are at least two peaks overlapped for all samples. The first peak in the range $150-300^{\circ} \mathrm{C}$ represents sites with weak alkalinity, while the peaks at higher temperatures (in the range $300-600^{\circ} \mathrm{C}$ ) are related to the desorption of $\mathrm{CO}_{2}$ from stronger basic sites. Additionally, Table 3 presents the estimated temperature for the different types of sites by deconvolution of the peaks. The total area of the sites with weaker and stronger alkalinity provides an idea about the amount of each type of site. From Figure 4, the curves have different shapes according to the promoter added to the sample. The LaCoAl catalyst exhibits a different profile

Table 3. $\mathrm{CO}_{2}$-TPD data for calcined samples.

\begin{tabular}{ccccccc}
\hline \multirow{2}{*}{ Sample } & \multicolumn{2}{c}{ Sites with weaker alkalinity } & \multicolumn{3}{c}{ Sites with stronger alkalinity } \\
\cline { 2 - 6 } & $\mathbf{1}^{\text {st }}$ peak $\left({ }^{\circ} \mathbf{C}\right)$ & Area (a.u.) & $\mathbf{1}^{\text {st }}$ peak $\left({ }^{\circ} \mathbf{C}\right)$ & $\mathbf{2}^{\text {nd }}$ peak $\left({ }^{\circ} \mathbf{C}\right)$ & $\mathbf{3}^{\text {rd }}$ peak $\left({ }^{\circ} \mathbf{C}\right)$ & Area $($ a.u. $)$ \\
\hline $\mathrm{CoAl}$ & 209 & 286 & 381 & 503 & - & 455 \\
$\mathrm{CaCoAl}$ & 218 & 345 & 352 & 418 & 579 & 534 \\
$\mathrm{LaCoAl}$ & 196 & 202 & 307 & 536 & - & 641 \\
$\mathrm{LiCoAl}$ & 233 & 140 & 454 & - & - & 400 \\
$\mathrm{MgCoAl}$ & 204 & 345 & 382 & 551 & - & 797 \\
\hline
\end{tabular}


because the peaks are predominantly shifted towards lower temperatures. This behaviour indicates that the strength of the basic sites is weaker for this material. The TPD profile for $\mathrm{LaCoAl}$ might be related to its different structure, mainly to the segregated $\mathrm{La}_{2} \mathrm{O}_{3}$ phase observed by XRD (Figure 2) for this sample. The areas related to $\mathrm{CO}_{2}$ uptake in Table 3 reveal an increase in the amount of sites with higher alkalinity for all the modified samples, except for LiCoAl. Thus, the overall $\mathrm{CO}_{2}$-TPD profiles depict the enhancement in the Lewis basicity of samples. Fakeeha et al. observed the same trend for Sr-promoted Co-Al catalysts ${ }^{12}$. However, Figure 4 highlights that the peaks are shifted towards higher temperatures for the $\mathrm{LiCoAl}$ material, thus providing evidence of the role of $\mathrm{Li}$ in the strength of the alkaline sites for this catalyst. The MgCoAl catalyst exhibited the highest amount of both the weaker and the stronger basic sites according to the area values showed in Table 3 . This result is in agreement with the different structure that led to the higher degree of reduction displayed by $\mathrm{MgCoAl}$ (see Table 2).

The catalytic performance at different reaction temperatures is shown in Figure 5 and Figure 6. Higher conversions of $\mathrm{CH}_{4}$ and $\mathrm{CO}_{2}$ are observed using the $\mathrm{MgCoAl}$ catalyst at all the reaction temperatures. The catalytic performance of both the $\mathrm{LaCoAl}$ and the $\mathrm{LiCoAl}$ catalysts also improves at higher temperatures, while the other two catalysts (i.e., $\mathrm{CoAl}$ and $\mathrm{CaCoAl}$ ) exhibit similar results. Therefore, the activity tests in Figure 5 cannot be correlated to the surface area and $\mathrm{Co}^{0}$ crystallite diameters (Table 2). Higher conversions of both gases is exhibited by the $\mathrm{LaCoAl}, \mathrm{LiCoAl}$ and $\mathrm{MgCoAl}$ catalysts, and this result is possibly related to the significant changes in the number ( $\mathrm{MgCoAl}$ and $\mathrm{LaCoAl}$ ) and strength ( $\mathrm{LiCoAl})$ of the basic sites in these samples, as shown in the TPD curves (see Table 3 and Figure 4). The alkali promotion might minimise carbon formation and hence favour the accessibility of reactants to the active sites. The same effect on activity was also reported by Fakeeha et al. for Sr-promoted cobalt catalysts $^{12}$. Additionally, the higher degree of reduction exhibited by $\mathrm{MgCoAl}$ (Table 2) also contributes to higher activity because the metallic Co phase is more active than the Co oxide species for the reforming reaction. The increase in the performance of Co-based catalysts promoted with small amounts of $\mathrm{Mg}$ was also observed for the partial oxidation of methane $\mathrm{e}^{50,51}$, as well as for $\mathrm{Mg}-\mathrm{Ni}-\mathrm{Al}$ catalysts for dry reforming ${ }^{22}$. The best activity of the $\mathrm{Mg}$-promoted sample was also found for supported Co-based catalysts promoted with earth metals for combined partial oxidation and $\mathrm{CO}_{2}$ reforming of methane to produce synthesis gas ${ }^{52,53}$. For the mixed oxides herein reported, the increase in the performance appears to be mostly related to the changes in the basicity of the active sites provided by the interaction between the alkali and Co oxides because the modified samples exhibit larger $\mathrm{Co}^{0}$ crystallite diameters compared to CoAl. As postulated elsewhere for Ni-supported samples ${ }^{15}$, the increase in the conversion of $\mathrm{CO}_{2}$ by the promotion of an alkali might be due to the formation of strongly ionic oxides. These oxides may attract the $\mathrm{CO}_{2}$ to the surface, increasing the conversion of methane as well. However, by adding a more electropositive alkali $(\mathrm{Ca})$, the cobalt electron density tends to increase significantly. The change in the electronic density should decrease the adsorption of methane and carbon dioxide. The decrease in adsorption could explain the lower effect of $\mathrm{Ca}$ promotion on the activity found for $\mathrm{CaCoAl}$.

The data for stability runs and carbon deposition on spent catalysts after $5 \mathrm{~h}$ at $500^{\circ} \mathrm{C}$ is summarised in Figures 7 and 8 , respectively.

Figure 7 shows a rapid decrease in the conversion of methane at the beginning of the reaction. As reported elsewhere, the three major phenomena that cause catalyst

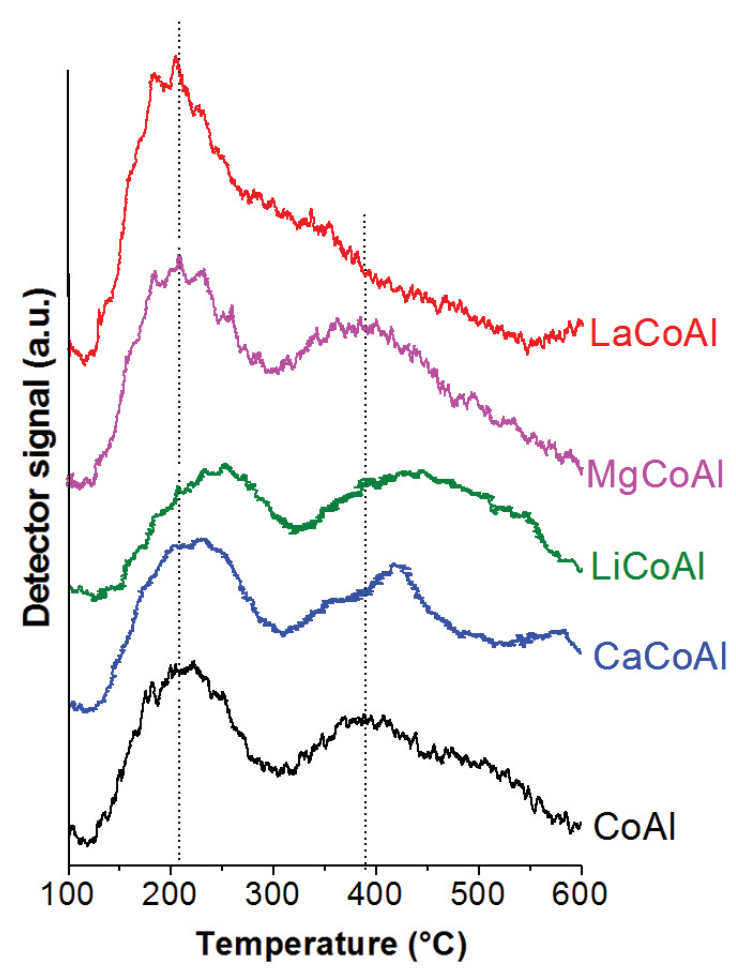

Figure 4. $\mathrm{CO}_{2}$-TPD curves.

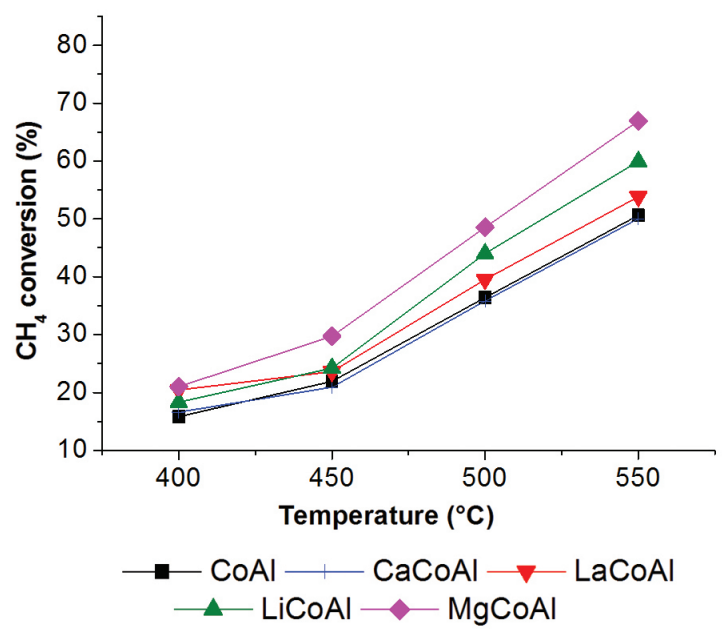

Figure 5. $\mathrm{CH}_{4}$ conversion vs. reaction temperature. 
deactivation during dry reforming of methane are sintering, metal oxidation and coking ${ }^{8,9}$. Initially, $\mathrm{Co}^{0}$ reoxidation might take place due to the presence of oxygen from the dissociation of $\mathrm{CO}_{2}$ because the coke accumulation and metal sintering mechanisms deactivate the catalyst more steadily and hence should require larger periods to affect the activity. After the aforementioned decrease in the methane conversion, catalysts show a stable activity profile, except for LaCoAl. Apparently, this sample has smaller $\mathrm{CH}_{4}$ conversions at the end of reaction, which could suggest that $\mathrm{LaCoAl}$ could deactivate faster due to sintering for longer runs. Among the investigated catalysts, LaCoAl appears to be the most susceptible to sintering because the TPR profiles (as shown in Figure 3) show that these Co oxide species reduce at the lowest temperatures, especially the segregated $\mathrm{Co}_{3} \mathrm{O}_{4}$ phase. While the performance of $\mathrm{CoAl}$, $\mathrm{CaCoAl}$ and $\mathrm{LiCoAl}$ is similar during the stability runs, the enhanced performance for the $\mathrm{MgCoAl}$ is remarkable. This performance follows the improved results found for this sample during tests at different reaction temperatures (see Figure 5 and Figure 6).

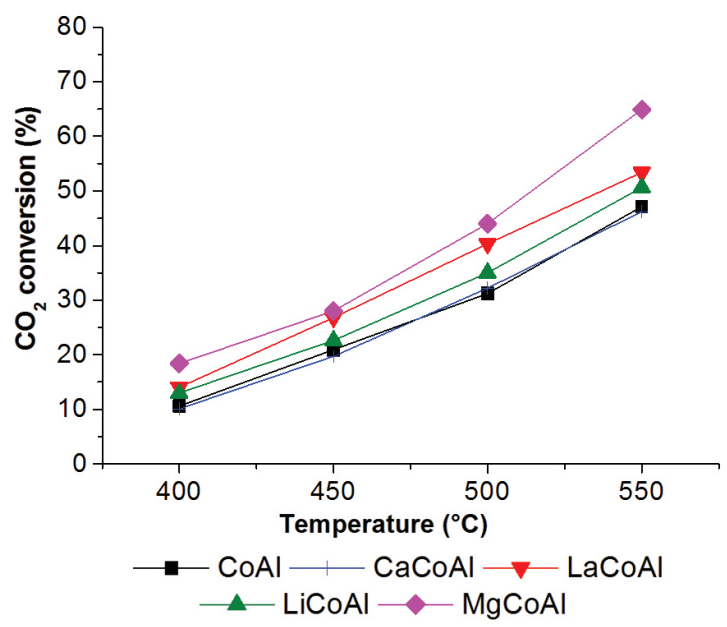

Figure 6. $\mathrm{CO}_{2}$ conversion vs. reaction temperature.

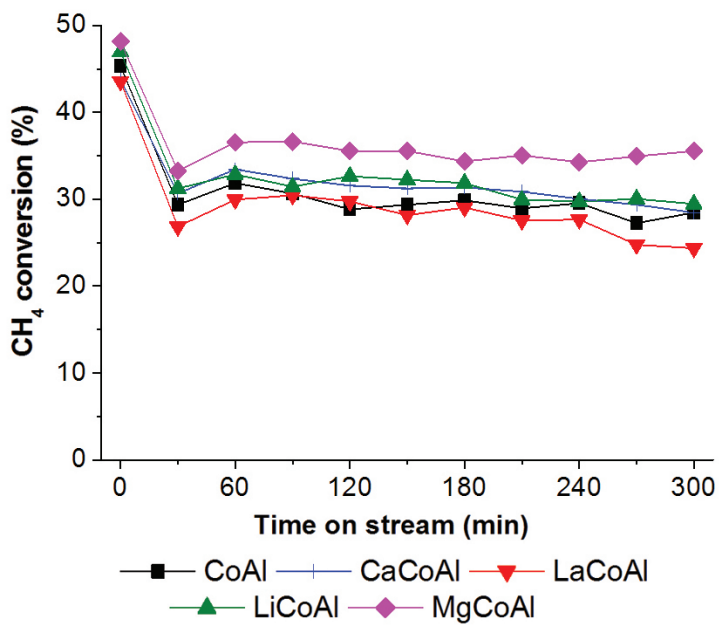

Figure 7. Evolution of $\mathrm{CH}_{4}$ conversion with time on stream.
Figure 8 displays the DTA peaks associated with the combustion of carbon and the relative amount of coke formed compared to the standard Co-Al sample (in parenthesis).

For these materials, the major drawback of adding the alkali is the growth in the size of the $\mathrm{Co}^{0}$ sites (Table 2). For the reforming processes, larger crystallites of the active metal are believed to promote coke formation, which is mainly observed for Ni-based catalysts ${ }^{26}$. However, Figure 8 shows that the carbon formation is lower for the modified catalysts because the addition of an alkali provides an increase in the number or strength of the basic sites (see the $\mathrm{CO}_{2}$-TPD results in Table 3 and Figure 4). Among the modified catalysts, the amount of carbon formed following the conversion of $\mathrm{CH}_{4}$ is displayed in Figure 5, except for LiCoAl. Indeed, this material experienced the lowest amount of carbon deposition. This result highlights the role of increased strength of the basic sites because the LiCoAl catalyst displayed the highest increase in strength for both the sites with weak and intermediate alkalinity while maintaining a high conversion of methane and carbon dioxide. Moreover, the $\mathrm{Co}^{0}$ crystallite size for $\mathrm{LiCoAl}$ is similar to the standard CoAl catalyst (Table 2) and might contribute to lower carbon deposition on this catalyst. Significantly less carbon forms using the LaCoAl catalyst compared to CoAl. This result is expected because of the higher amount of basic sites found on this material (Table 3). Moreover, the conversion of methane with time on stream after $4 \mathrm{~h}$ is lower for this sample (Figure 7), which would also be related to the low carbon deposition for the $\mathrm{LaCoAl}$ catalysts.

On the other hand, the DTA peaks associated with the combustion of carbon indicate that the temperature required for regeneration is similar. However, the coke formed by $\mathrm{MgCoAl}$ is oxidised at a temperature only $10^{\circ} \mathrm{C}$ higher than the standard CoAl catalyst.

Pronounced accumulation of carbon is known to occur for reforming of methane over cobalt catalysts with large

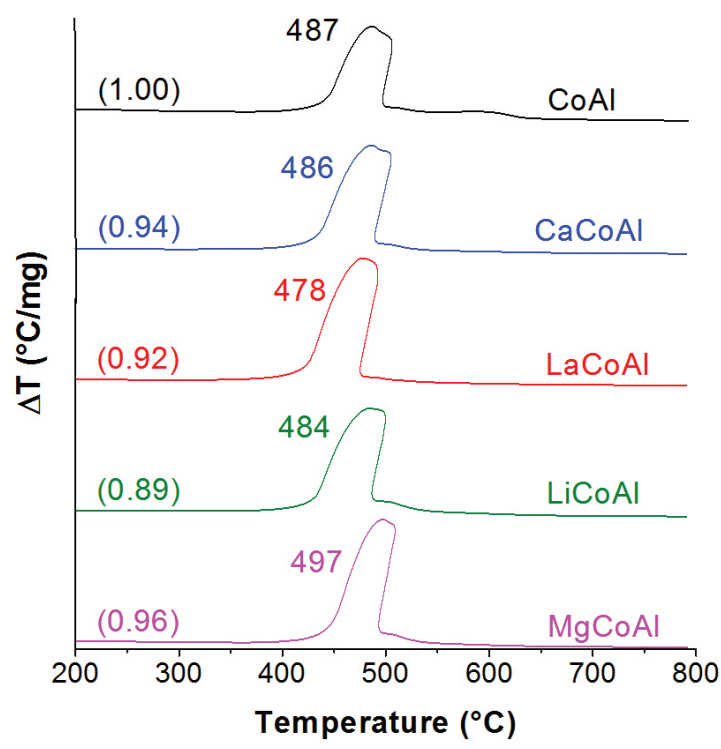

Figure 8. TPO/DTA curves for spent catalysts. 
crystallite sizes because small particles favour carbon gasification by $\mathrm{CO}_{2}{ }^{54}$. However, the overall stability of the catalysts in Figure 7 suggests that the carbon deposits do not cover all the active sites, and some of the sites are still available for the chemisorption and dissociation of methane and carbon dioxide. The literature reports that amorphous carbon could easily cover all the active sites, while filamentous carbon can grow without covering the metal surface ${ }^{8}$. Amorphous carbon oxidises at approximately $400^{\circ} \mathrm{C}$, while the DTA peaks in Figure 8 are centred at ca. $490^{\circ} \mathrm{C}$, which could be assigned to carbon nanotubes or nanofibres ${ }^{27,29,42}$. Therefore, the TPO/DTA analysis suggests that filamentous carbon is formed for the Co-Al samples investigated herein. This affirmation is also supported by scanning electronic microscopy (SEM) and Raman spectra collected by our group for the decomposition of methane or ethanol over similar Co-Al mixed oxides ${ }^{29,55}$. For both cases, the SEM images show filamentous tubes that cover the particle surface for the spent catalysts. Specifically, the ratio between the D- and G- bands from the Raman spectra suggest that multi-walled carbon nanotubes (MWCNT) or nanofibres are deposited on catalyst surface after ethanol decomposition. De Sousa et al. observed the same MWCNT structure for dry reforming of methane over $\mathrm{Ni}$-spinel oxides $^{27}$. The $\mathrm{CoAl}_{2} \mathrm{O}_{4}$ species are also ascribed to prevent carbon deposition that could lead to deactivation after coking ${ }^{9}$. Based on previous results and on a review of the literature for the relationship between the carbonaceous material and crystalline structure referred above, the catalyst stability in the conversion of methane (Figure 7) can be ascribed mostly to the formation of carbon filaments that do not encapsulate the active metal sites and thus keep the activity stable, which is favoured by the presence of cobalt aluminate species.

\section{Conclusions}

A series of Co-based materials promoted with alkalis was synthesised and evaluated for dry reforming of methane

\section{References}

1. Dry ME. The fischer-tropsch process: 1950-2000. Catal Today. 2002; 71(3):227-241. http://dx.doi.org/10.1016/S09205861(01)00453-9

2. Feio LSF, Hori CE, Mattos LV, Zanchet D, Noronha FB and Bueno JMC. Partial oxidation and autothermal reforming of methane on $\mathrm{Pd} / \mathrm{CeO} 2-\mathrm{Al} 2 \mathrm{O} 3$ catalysts. Appl Catal A Gen. 2008; 348(2):183-192. http://dx.doi.org/10.1016/j. apcata.2008.06.030

3. Jones G, Jakobsen JG, Shim SS, Kleis J, Andersson MP, Rossmeisl J et al. First principles calculations and experimental insight into methane steam reforming over transition metal catalysts. J Catal. 2008; 259(1):147-160. http://dx.doi. org/10.1016/j.jcat.2008.08.003

4. Rostrup-Nielsen JR and Hansen JHB. CO2-reforming of methane over transition metals. J Catal. 1993; 144(1):38-49. http://dx.doi.org/10.1006/jcat.1993.1312

5. Bouarab R, Akdim O, Auroux A, Cherifi O and Mirodatos C. Effect of $\mathrm{MgO}$ additive on catalytic properties of $\mathrm{Co} / \mathrm{SiO} 2$ in the dry reforming of methane. Appl Catal A Gen. 2004; 264(2):161168. http://dx.doi.org/10.1016/j.apcata.2003.12.039 at moderate temperatures. The partial substitution of small quantities of $\mathrm{Co}$ by $\mathrm{Ca}, \mathrm{La}, \mathrm{Li}$ or $\mathrm{Mg}$ modifies the reducibility of the Co species and the crystallinity of the oxides in the structure. A small increase in the specific area and an increase in the alkaline properties of the materials were also noted. These changes in the material influence the catalytic properties for dry reforming of methane and for carbon formation, mostly for the $\mathrm{Mg}$ - and Li-promoted samples.

Despite having shown smaller metallic Co crystallite sizes, the unpromoted catalyst ( $\mathrm{CoAl})$ exhibited the lowest activity (conversions of $\mathrm{CO}_{2}$ and $\mathrm{CH}_{4}$ ) for all the reaction temperature range. This result might be due to the higher coke formation rate attributed to the higher acidity of the catalyst. On the other hand, all the alkali-promoted catalysts exhibited lower carbon deposition after a decrease in the acidity or an increase in the strength of the alkaline sites for these materials.

The Li-containing sample presented the highest strength of both the weak and the strong basic sites. These properties provided the lowest carbon formation for the LiCoAl catalyst.

Among all the samples, the sample modified with $\mathrm{Mg}$ showed the best performance for dry reforming of methane. This result can be attributed to the commitment between textural properties (surface area), reducibility and acid/base properties. The best activity was achieved at $550^{\circ} \mathrm{C}$, which is a moderate temperature for this reaction. The mixed oxides might favour the formation of non-deactivating coke, thus the stable activity observed in the stability experiments.

\section{Acknowledgements}

The authors thank the financial support granted by CAPES (Coordenação de Aperfeiçoamento de Pessoal de Pessoal de Nível Superior) and CNPq (Conselho Nacional de Desenvolvimento Científico e Tecnológico) to carry out this work.

6. Luisetto I, Tuti S and Di Bartolomeo E. Co and Ni supported on $\mathrm{CeO} 2$ as selective bimetallic catalyst for dry reforming of methane. Int J Hydrogen Energy. 2012; 37(21):15992-15999. http://dx.doi.org/10.1016/j.ijhydene.2012.08.006

7. San-José-Alonso D, Juan-Juan J, Illán-Gómez MJ and RománMartínez MC. Ni, Co and bimetallic Ni-Co catalysts for the dry reforming of methane. Appl Catal A Gen. 2009; 371(1-2):5459. http://dx.doi.org/10.1016/j.apcata.2009.09.026

8. Ewbank JL, Kovarik L, Kenvin CC and Sievers C. Effect of preparation methods on the performance of $\mathrm{Co} / \mathrm{Al} 2 \mathrm{O} 3$ catalysts for dry reforming of methane. Green Chem. 2014; 16(2):885896. http://dx.doi.org/10.1039/c3gc41782d

9. Budiman A, Song SH, Chang TS, Shin $\mathrm{CH}$ and Choi MJ. Dry reforming of methane over cobalt catalysts: a literature review of catalyst development. Catal. Surv. Asia. 2012; 16(4):183-197. http://dx.doi.org/10.1007/s10563-012-9143-2

10. Nagaoka K, Takanabe K and Aika KI. Modification of $\mathrm{Co} /$ $\mathrm{TiO} 2$ for dry reforming of methane at $2 \mathrm{MPa}$ by $\mathrm{Pt}, \mathrm{Ru}$ or Ni. Appl Catal A Gen. 2004; 268(1-2):151-158. http://dx.doi. org/10.1016/j.apcata.2004.03.029 
11. Nagaoka K, Takanabe $K$ and Aika KI. Influence of the reduction temperature on catalytic activity of $\mathrm{Co} / \mathrm{TiO} 2$ (anatase-type) for high pressure dry reforming of methane. Appl Catal A Gen. 2003; 255(1):13-21. http://dx.doi.org/10.1016/S0926860X(03)00631-8

12. Fakeeha AH, Naeem MA, Khan WU and Al-Fatesh AS. Syngas production via $\mathrm{CO} 2$ reforming of methane using $\mathrm{Co}-\mathrm{Sr}-\mathrm{Al}$ catalyst. Ind Eng Chem. 2014; 20(2):549-557. http://dx.doi. org/10.1016/j.jiec.2013.05.013

13. Ruckenstein $\mathrm{E}$ and $\mathrm{Hu} \mathrm{YH}$. Carbon dioxide reforming of methane over nickel/alkaline earth metal oxide catalysts. Appl Catal A Gen. 1995; 133(1):149-161. http://dx.doi. org/10.1016/0926-860X(95)00201-4

14. Quincoces CE, Dicundo S, Alvarez AM and González MG. Effect of addition of $\mathrm{CaO}$ on $\mathrm{Ni} / \mathrm{A} 12 \mathrm{O} 3$ catalysts over $\mathrm{CO} 2$ reforming of methane. Mater Lett. 2001; 50(1):21-27. http:// dx.doi.org/10.1016/S0167-577X(00)00406-7

15. Dias JAC and Assaf JM. Influence of calcium content in $\mathrm{Ni} /$ $\mathrm{CaO} / \gamma-\mathrm{Al}_{2} \mathrm{O}_{3}$ catalysts for $\mathrm{CO}_{2}$-reforming of methane. Catal Today. 2003; 85(1):59-68. http://dx.doi.org/10.1016/S09205861(03)00194-9

16. Hou Z, Yokota O, Tanaka $\mathrm{T}$ and Yashima T. Characterization of Ca-promoted Ni/ $\alpha-\mathrm{Al}_{2} \mathrm{O}_{3}$ catalyst for $\mathrm{CH}_{4}$ reforming with CO. Appl Catal A Gen. 2003; 253(2):381-387. http://dx.doi. org/10.1016/S0926-860X(03)00543-X

17. Jing Q, Lou H, Mo L, Fei J and Zheng X. Combination of $\mathrm{CO} 2$ reforming and partial oxidation of methane over $\mathrm{Ni} / \mathrm{BaO}-\mathrm{SiO}_{2}$ catalysts to produce low $\mathrm{H} 2 / \mathrm{CO}$ ratio syngas using a fluidized bed reactor. J Mol Catal A Chem. 2004; 212(1-2):211-217. http://dx.doi.org/10.1016/j.molcata.2003.10.041

18. Juan-Juan J, Román-Martínez MC and Illán-Gómez MJ. Effect of potassium content in the activity of K-promoted $\mathrm{Ni} / \mathrm{Al}_{2} \mathrm{O}_{3}$ catalysts for the dry reforming of methane. Appl Catal A Gen. 2006; 301(1):9-15. http://dx.doi.org/10.1016/j. apcata.2005.11.006

19. Barroso-Quiroga MM and Castro-Luna AE. Catalytic activity and effect of modifiers on Ni-based catalysts for the dry reforming of methane. Int $J$ Hydrogen Energy. 2010; 35(11):6052-6056. http://dx.doi.org/10.1016/j. ijhydene.2009.12.073

20. Vaccari A. Clays and catalysis: a promising future. Appl Clay Sci. 1999; 14(4):161-198. http://dx.doi.org/10.1016/S01691317(98)00058-1

21. Trifiró F and Vaccari A. Hydrotalcite-like anionic clays (layer double hydroxides): comprehensive supramolecular chemistry. Oxford: Pergamon; 1996. v. 257. p. 251.

22. Perez-Lopez OW, Senger A, Marcilio NR and Lansarin MA. Effect of composition and thermal pretreatment on properties of $\mathrm{Ni}-\mathrm{Mg}-\mathrm{Al}$ catalysts for $\mathrm{CO}_{2}$ reforming of methane. Appl Catal A Gen. 2006; 303(2):234-244. http://dx.doi.org/10.1016/j. apcata.2006.02.024

23. Guo JJ, Lou H, Zhao H, Chai DF and Zheng XM. Dry reforming of methane over nickel catalysts supported on magnesium aluminate spinels. Appl Catal A Gen. 2004; 273(1-2):75-82. http://dx.doi.org/10.1016/j.apcata.2004.06.014

24. Daza CE, Gallego J, Moreno JA, Mondragon F, Moreno S and Molina R. $\mathrm{CO}_{2}$ reforming of methane over $\mathrm{Ni} / \mathrm{Mg} / \mathrm{Al} / \mathrm{Ce}$ mixed oxides. Catal Today. 2008; 133-135:357-366. http://dx.doi. org/10.1016/j.cattod.2007.12.081

25. Hou $\mathrm{Z}$ and Yashima T. Meso-porous $\mathrm{Ni} / \mathrm{Mg} / \mathrm{Al}$ catalysts for methane reforming with $\mathrm{CO}_{2}$. Appl Catal A Gen. 2004; 261(2):205-209. http://dx.doi.org/10.1016/j. apcata.2003.11.002
26. Bhattacharyya A, Chang VW and Schumacher DJ. $\mathrm{CO}_{2}$ reforming of methane to syngas: I: evaluation of hydrotalcite clay-derived catalysts. Appl Clay Sci. 1998; 13(5-6):317-328. http://dx.doi.org/10.1016/S0169-1317(98)00030-1

27. De Sousa FF, Sousa HAS, Oliveira AC, Junior MCC, Ayala AP, Barros EB et al. Nanostructured Ni-containing spinel oxides for the dry reforming of methane: effect of the presence of cobalt and nickel on the deactivation behaviour of catalysts. Int J Hydrogen Energy. 2012; 37(4):3201-3212. http://dx.doi. org/10.1016/j.ijhydene.2011.11.072

28. Serrano-Lotina A, Martin AJ, Folgado MA and Daza L. Dry reforming of methane to syngas over La-promoted hydrotalcite clay-derived catalysts. Int J Hydrogen Energy. 2012; 37(17):12342-12350. http://dx.doi.org/10.1016/j. ijhydene.2012.06.041

29. Hermes NA, Lansarin MA and Perez-Lopez OW. Catalytic decomposition of methane over $\mathrm{M}-\mathrm{Co}-\mathrm{Al}$ catalysts $(\mathrm{M}=\mathrm{Mg}$, $\mathrm{Ni}, \mathrm{Zn}, \mathrm{Cu}$ ). Catal Letters. 2011; 141(7):1018-1025. http:// dx.doi.org/10.1007/s10562-011-0611-5

30. Khassin AA, Yurieva TM, Kustova GN, Itenberg IS, Demeshkina MP, Krieger TA et al. Cobalt-aluminum coprecipitated catalysts and their performance in the FischerTropsch synthesis. J Mol Catal A Chem. 2001; 168(1-2):193207. http://dx.doi.org/10.1016/S1381-1169(00)00529-X

31. Reshetenko TV, Avdeeva LB, Khassin AA, Kustova GN, Ushakov VA, Moroz EM et al. Coprecipitated iron-containing catalysts (Fe-Al2O3, Fe-Co-Al2O3, Fe-Ni- Al2O3) for methane decomposition at moderate temperatures i. Genesis of calcined and reduced catalysts. Appl Catal A Gen. 2004; 268(12):127-138. http://dx.doi.org/10.1016/j.apcata.2004.03.045

32. Ross JRH. Natural gas reforming and $\mathrm{CO} 2$ mitigation. Catal Today. 2005; 100(1-2):151-158. http://dx.doi.org/10.1016/j. cattod.2005.03.044

33. Serrano-Lotina A and Daza L. Influence of the operating parameters over dry reforming of methane to syngas. Int J Hydrogen Energy. 2014; 39(8):4089-4094. http://dx.doi. org/10.1016/j.ijhydene.2013.05.135

34. Yu XP, Chu W, Wang $\mathrm{N}$ and Ma F. Hydrogen production by ethanol steam reforming on $\mathrm{NiCuMgAl}$ catalysts derived from hydrotalcite-like precursors. Catal Letters. 2011; 141(8):12281236. http://dx.doi.org/10.1007/s10562-011-0608-0

35. Palmer SJ, Spratt HJ and Frost RL. Thermal decomposition of hydrotalcites with variable cationic ratios. J Therm Anal Calorim. 2009; 95(1):123-129. http://dx.doi.org/10.1007/ s10973-008-8992-4

36. Vaccari A. Preparation and catalytic properties of cationic and anionic clays. Catal Today. 1998; 41(1-3):53-71. http://dx.doi. org/10.1016/S0920-5861(98)00038-8

37. Holgado MJ, Rives V and San Roman MS. Characterization of $\mathrm{Ni}-\mathrm{Mg}-\mathrm{Al}$ mixed oxides and their catalytic activity in oxidative dehydrogenation of n-butane and propene. Appl Catal A Gen. 2001; 214(2):219-228. http://dx.doi.org/10.1016/ S0926-860X(01)00496-3

38. Souza G, Ávila VC, Marcílio NR and Perez-Lopez OW. Synthesis Gas Production by Steam Reforming of Ethanol over M-Ni-Al Hydrotalcite-type Catalysts; $\mathrm{M}=\mathrm{Mg}, \mathrm{Zn}, \mathrm{Mo}$, Co. Procedia Eng. 2012; 42:1805-1815. http://dx.doi.org/10.1016/j. proeng.2012.07.575

39. Lopez-Salinas E, Garcia-Sanchez M, Luisa Ramon-Garcia M and Schifter I. New gallium-substituted hydrotalcites: [Mg1xGax $(\mathrm{OH}) 2](\mathrm{CO} 3) \mathrm{x} / 2 \cdot m \mathrm{H} 2 \mathrm{O}$. J Porous Mat. 1996; 3(3):169174. http://dx.doi.org/10.1007/BF01134028

40. Wang DY, Leuteritz A, Wagenknecht U and Heinrich G. Self-assembling organomodified $\mathrm{Co} / \mathrm{Al}$ based layered double 
hydroxides (LDH) via one-step route. Trans. Nonferrous Met. Soc. China. 2009; 19(6):1479-1482. http://dx.doi.org/10.1016/ S1003-6326(09)60055-8

41. Xu W, Liu X, Ren J, Liu H, Ma Y, Wang Y et al. Synthesis of nanosized mesoporous Co-Al spinel and its application as solid base catalyst. Microporous Mesoporous Mater. 2011; 142(1):251-257. http://dx.doi.org/10.1016/j. micromeso.2010.12.008

42. Escobar C and Perez-Lopez OW. Hydrogen production by methane decomposition over $\mathrm{Cu}-\mathrm{Co}-\mathrm{Al}$ Mixed oxides activated under reaction conditions. Catal Letters. 2014; 144(5):796-804. http://dx.doi.org/10.1007/s10562-014-1234-4

43. Hu X and Lu G. Acetic acid steam reforming to hydrogen over $\mathrm{Co}-\mathrm{Ce} / \mathrm{A} 12 \mathrm{O} 3$ and $\mathrm{Co}-\mathrm{La} / \mathrm{A} 12 \mathrm{O} 3$ catalysts: the promotion effect of Ce and La addition. Catal Commun. 2010; 12(1):5053. http://dx.doi.org/10.1016/j.catcom.2010.07.015

44. Ribet S, Tichit D, Coq B, Ducourant B and Morato F. Synthesis and activation of Co-Mg-Al layered double hydroxides. J Solid State Chem. 1999; 142(2):382-392. http://dx.doi.org/10.1006/ jssc. 1998.8053

45. Gabrovska M, Edreva-Kardjieva R, Tenchev K, Tzvetkov P, Spojakina A and Petrov L. Effect of Co-content on the structure and activity of $\mathrm{Co}-\mathrm{Al}$ hydrotalcite-like materials as catalyst precursors for CO oxidation. Appl Catal A Gen. 2011; 399(12):242-251. http://dx.doi.org/10.1016/j.apcata.2011.04.007

46. Benito R, Herrero M, Labajos FM, Rives V, Royo C, Latorre $\mathrm{N}$ et al. Production of carbon nanotubes from methane use of Co-Zn-Al catalysts prepared by microwave-assisted synthesis. Chem Eng J. 2009; 149(1-3):455-462. http://dx.doi. org/10.1016/j.cej.2009.02.022

47. Bialas A, Niebrzydowska P, Dudek B, Piwowarska Z, Chmielarz L, Michalik M et al. Coprecipitated Co-Al and $\mathrm{Cu}-\mathrm{Al}$ oxide catalysts for toluene total oxidation. Catal Today. 2011; 176(1):413-416. http://dx.doi.org/10.1016/j. cattod.2010.11.021
48. Nudel JN, Umansky BS and Lombardo EA. Bulk, surface and catalytic characterization of the $\mathrm{Co} 3 \mathrm{O} 4-\mathrm{La} 2 \mathrm{O} 3-\mathrm{Al} 2 \mathrm{O} 3$ system. Appl Catal A Gen. 1987; 31(2):275-289. http://dx.doi. org/10.1016/S0166-9834(00)80697-1

49. Gennequin C, Kouassi S, Tidahy L, Cousin R, Lamonier JF, Garcon $\mathrm{G}$ et al. $\mathrm{Co}-\mathrm{Mg}-\mathrm{Al}$ oxides issued of hydrotalcite precursors for total oxidation of volatile organic compounds: identification and toxicological impact of the by-products. $C$ $R$ Chim. 2010; 13(5):494-501. http://dx.doi.org/10.1016/j. crci.2010.01.001

50. Sokolovskii VD, Coville NJ, Parmaliana A, Eskendirov I and Makoa M. Methane partial oxidation: challenge and perspective. Catal Today. 1998; 42(3):191-195. http://dx.doi. org/10.1016/S0920-5861(98)00091-1

51. Choudhary VR, Sansare SD and Mamman AS. Lowtemperature selective oxidation of methane to carbon monoxide and hydrogen over cobalt-MgO catalysts. Appl Catal A Gen. 1992; 90(1):L1-L5. http://dx.doi.org/10.1016/0926860X(92)80242-5

52. Ruckenstein E and Wang HY. Combined catalytic partial oxidation and $\mathrm{CO} 2$ reforming of methane over supported cobalt catalysts. Catal Letters. 2001; 73(2-4):99-105. http://dx.doi. org/10.1023/A:1016695830055

53. Wang HY and Ruckenstein E. Partial oxidation of methane to synthesis gas over alkaline earth metal oxide supported cobalt catalysts. Journal of Catalysis. 2001; 199(2):309-317. http:// dx.doi.org/10.1006/jcat.2001.3190

54. Segner J, Campbell CT, Doyen G and Ertl G. Catalytic oxidation of $\mathrm{CO}$ on $\mathrm{Pt}(111)$ : the influence of surface defects and composition on the reaction dynamics. Surf Sci. 1984; 138(23):505-523. http://dx.doi.org/10.1016/0039-6028(84)90262-0

55. Ruoso C, Souza G, Balzaretti NM, Marcilio NR and PerezLopez OW. Nanotubos de carbono a partir da decomposição do etanol sobre catalisadores Co-Al. In: Proceedings of the Brazilian Congress on Chemical Engineering; 2012; Búzios, Brasil. ABEQ; 2012. p. 8846-8854. 